\title{
Suppression of Bacterial Wilt and Fusarium Wilt by a Burkholderia nodosa Strain Isolated from Kalimantan Soils, Indonesia
}

\author{
YANETRI ASI NION ${ }^{1,2}$, and KOKI TOYOTA ${ }^{1 *}$ \\ ${ }^{1}$ Graduate School of Bio-Applications and Systems Engineering, Tokyo University of Agriculture and Technology, \\ 2-24-16, Naka-cho, Koganei, Tokyo 184-8588, Japan; and ${ }^{2}$ Faculty of Agriculture, University of Palangkaraya, \\ Palangkaraya 73112, Central Kalimantan, Indonesia
}

(Received October 13, 2007-Accepted February 9, 2008)

A trial was conducted to suppress bacterial wilt of tomato (BWT) caused by Ralstonia solanacearum using biocontrol agents (BCAs) isolated from soils in Kalimantan, Indonesia. Five isolates were selected from 270 isolates as better performing BCAs through screening four times using a pumice medium. The isolates selected were identified as Burkholderia nodosa, Burkholderia sacchari, Burkholderia pyrrocinia and Burkholderia terricola according to $16 \mathrm{~S}$ rDNA sequences, fatty acid composition and carbon source utilization patterns. Among them, B. nodosa G5.2.rif1 had significant suppressive effects on Fusarium wilt of tomato (FWT) and spinach (FWS) as well as BWT. When $B$. nodosa G5.2rifl was inoculated into a pumice medium in combination with sucrose, it showed even more stable disease suppression for BWT, but not for FWS. This suppression was considered to mainly occur through competition for nutrients. In two times greenhouse experiments for BWT using pots comparable in size to those used commercially, $B$. nodosa G5.2rif1 significantly suppressed the disease index by 33-79\%, with no inhibitory effects on the growth, yield and quality of tomatoes.

Key words: screening, biocontrol agent, bacterial wilt, enhancement, sucrose

Soil-borne pathogens have been one of the major constraints to crop production. Disease control has been accomplished through the breeding of resistant varieties, crop rotations, cultivation techniques, additions of composts etc., but is largely dependent on the use of synthetic chemical pesticides $^{43}$. However, there is growing concern over the increased use of such pesticides to support agricultural production because of effects on mainly non-target organisms ${ }^{23)}$. In addition, leaching into underground water, run-off and volatilization of chemicals can cause environmental pollution ${ }^{37)}$. Therefore, biocontrol agents (BCAs) have attracted much attention as an alternative to the use of chemicals for disease control $7,23,42$ ).

BCAs are sustained by various beneficial interactions such as competition for nutrients and space, antibiosis, parasitism and induced systemic resistance ${ }^{1,7,29)}$. Currently, several microorganisms possessing some of these properties are being used as active ingredients in a new generation of microbial pesticides ${ }^{1,23,43)}$.

BCAs are promising agents for the control of soil-borne plant diseases but a major problem is inconsistent colonization and so poor performance ${ }^{31,35)}$. In addition, not all species survive well in soil, because BCAs are not indigenous to the soil or because they poorly respond to diverse soil conditions. Important features in the colonization of soil and root by inoculated microorganisms are their persistence and expression of activity, which result in success of their application ${ }^{40)}$. The addition of carbon substrates is considered one effective method to enhance the colonization of BCAs. Carbon sources can increase growth rates of certain types of

* Corresponding author. E-mail: kokit@cc.tuat.ac.jp rhizosphere microorganisms and thereby affect competition for space and nutrients, resulting in a modified community of microorganisms $s^{9,15,16,19,41}$ ). Our previous study also found that the addition of organic compounds such as glucose and lysine had a conducive suppressive effect against bacterial wilt of tomato, possibly through modification of the indigenous microbial community ${ }^{26)}$.

Soils from Kalimantan in Indonesia were selected since there have been no reports on the isolation of BCAs from this area, in spite that Kalimantan is well known to be rich in microbial resources. For example, phosphorus-solubilizing microorganisms, nitrogen-fixing bacteria, decomposers and mycorrhizal fungi, have been studied ${ }^{3,27,28,34)}$. The purpose of this study is to screen BCAs from Kalimantan soils that would protect vegetables from soil-borne diseases and to examine a combination with organic carbons that enhance the activity of BCAs. In addition, the effect of the BCAs on the yield and quality of tomato was evaluated.

\section{Materials and Methods}

\section{Strains and soils}

The pathogens used in this study were Ralstonia solanacearum YU1Rif43 ${ }^{36)}$, Fusarium oxysporum f. sp. lycopersici 880621a, race 2 and $F$. oxysporum f. sp. spinaciae GF-2. The bacterial strain was cultured overnight at $28^{\circ} \mathrm{C}$ in one tenth strength nutrient broth $(1 / 10$ NB) medium (Eiken Chemical Co., Ltd., Tokyo, Japan). The $F$. oxysporum strains were cultured in Czapeck medium ${ }^{10}$ for one week at $28^{\circ} \mathrm{C}$ on a NR-2 rotary shaker (Taitec Co., Ltd. Japan) at 75 $\mathrm{rpm}$, and bud-cells were obtained by passing the culture through a funnel glass filled with absorbent cotton (Hasegawa Mengyo Co., Ltd., Aichi, Japan).

Histosols (peat) and spodosols (kerangas) were collected from Kalimantan, Indonesia and used as sources of biocontrol agents. For 
the histosol soils, we took 5 samples from different areas in agricultural fields (three fields planted with corn, a field planted with grasses, and a field planted with pumpkin) and 4 samples from different habitats (a burnt forest and a natural forest in Kalampangan, and two secondary forests in Setia Alam). A spodosol soil sample was collected from a secondary forest in the Tangkiling area. Some of the chemical and physical properties of the soils have been reported previously ${ }^{33)}$

\section{Isolation of biocontrol agents}

Disease suppressive properties of BCAs were tested first against bacterial wilt of tomato (BWT) and then against Fusarium wilt of tomato (FWT) and Fusarium wilt of spinach (FWS). A total of 270 bacterial isolates were isolated from the soils using a one tenth strength nutrient agar medium (Eiken Chemical Co., Ltd., Tokyo, Japan) supplemented with $0.1 \mathrm{mg} \mathrm{L}^{-1}$ of crystal violet (CV medium ${ }^{14)}$ ), since our preliminary study suggested the a frequency of isolates with high biocontrol ability to be highest when CV medium was used as an isolation medium (data not shown). Ten grams of each soil sample was mixed with $90 \mathrm{ml}$ of sterile distilled water and shaken by a Vortex-Genie 2 (Scientific Industries Inc., New York, USA) for one minute. Serial dilutions of $10^{-1}$ up to $10^{-6}$ were prepared and the aliquots $(0.1 \mathrm{ml})$ were plated on $\mathrm{CV}$ medium. The plates were incubated at $28^{\circ} \mathrm{C}$ for 3 days and the total number of colonies was calculated as CFUs (colony forming units per gram soil). For each soil sample, 25 isolates were randomly picked. A colony of bacteria was suspended in a tube containing $20 \%(\mathrm{w} / \mathrm{v})$ glycerol and stored at $-85^{\circ} \mathrm{C}$ until further use.

\section{Screening of biocontrol agents against bacterial wilt of tomato (climatron experiment)}

Four times screenings of BCAs were conducted for BWT. In the first screening, for each treatment, the 5 strains $(1 \mathrm{ml}$ overnight culture using 1/10 NB per strain) were combined and poured into a vinyl pot (Sakata Seed Co., Yokohama, Japan) $7 \mathrm{~cm}$ in diameter and $9 \mathrm{~cm}$ in height, containing $65 \mathrm{~g}$ of pumice and supplemented with $\mathrm{CaCO}_{3}$ at a rate of $15 \mathrm{~g} \mathrm{~kg}^{-1}$ for neutralization. The pumice (Eco-

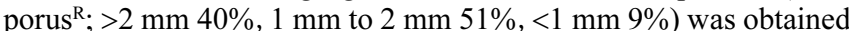
from Ebara Co., Tokyo, Japan. Six tomato (Lycopersicon esculentum Mill cv. Momotaro) seeds (Takii Co., Ltd., Kyoto, Japan) pregerminated for 2 days were transplanted to the pot by using sterile forceps. The seeds were grown for two weeks in a climatron (LPH200, Nippon Medical \& Chemical Instruments Co., Ltd., Osaka, Japan; day:night=12h:12h, $285 \mu \mathrm{mol} \mathrm{m}^{-2} \mathrm{~s}^{-1}$ (photon flux) at $28^{\circ} \mathrm{C}$ ). Watering was done daily using Otsuka liquid fertilizer A formula (Otsuka Chemical Co., Ltd., Osaka, Japan; pH 3.8, N 260, P $120, \mathrm{~K} 405, \mathrm{Ca} 230, \mathrm{Mg} 60, \mathrm{Mn} 1.5, \mathrm{~B} 1.5$, Fe 2.7, Cu 0.03, Zn 0.09 , Mo $0.03\left(\mathrm{mg} \mathrm{L}^{-1}\right)$. After two weeks, six seedlings with pumice from the old pot were transplanted to a new vinyl pot $9 \mathrm{~cm}$ in diameter and $7.5 \mathrm{~cm}$ in height containing $55 \mathrm{~g}$ of pumice inoculated with $R$. solanacearum YU1Rif43 at a rate of $10^{4} \mathrm{cfu} \mathrm{g}^{-1}$. In this screening, control - (no inoculation of BCAs and the pathogen) and control+(inoculation of only the pathogen) were also prepared. This experiment was done in triplicate. The numbers of wilted plants were recorded at 2-day intervals for 30 days after transplanting to the pot infested with the pathogen on the following basis: 0 ; no wilt symptoms, $1 ; 0$ to $25 \%$ of plant showing wilting, $2 ; 26$ to $50 \%, 3 ; 51$ to $75 \%, 4 ; 76$ to $100 \%$. A disease index was expressed as the mean for triplicate pots, each consisting of 6 plants.

In the second to fourth screening, the same method as described above was used, except for the application of BCAs, in which a single strain selected from the first screening was inoculated into each pot.

\section{Identification of $B C A$ s}

Strains that showed consistent disease suppression were grown in 1/10 NB for $24 \mathrm{~h}$ and DNA was extracted from the bacterial strains with the conventional method ${ }^{22}$. The primers (27f) 5'AGAGTTTGATCCTGGCTCAG-3` and (1378r) 5'-TACAAGGC-
CCGGGAACG-3' were used to amplify the segment of the bacterial 16S rDNA from nucleotides 27 to 1378 (Escherichia coli numbering $)^{21}$. PCR was carried out using a basic reaction mixture containing an Ex Taq buffer (Takara, Otsu, Japan), $2.5 \mathrm{mM}$ of each deoxyribonucleotide triphosphate, $2.5 \mathrm{U}$ of Ex Taq (Takara), $0.25 \mathrm{mM}$ of each oligonucleotide primer, and $1 \mu 1$ of template (purified DNA) in a total volume of $25 \mu \mathrm{l}$. The thermocycling conditions consisted of an initial denaturing step at $94^{\circ} \mathrm{C}$ for $3 \mathrm{~min}, 30$ amplification cycles of $94^{\circ} \mathrm{C}$ for $1 \mathrm{~min}, 55^{\circ} \mathrm{C}$ for $1 \mathrm{~min}$, and $72^{\circ} \mathrm{C}$ for $3 \mathrm{~min}$, and a final step at $72^{\circ} \mathrm{C}$ for $7 \mathrm{~min}$ with a GeneAmp PCR System (PCR Thermal Cycler, PERSONAL, Takara). The PCR products were confirmed in electrophoresis using an agarose gel with $0.5 \mu \mathrm{g} \mathrm{ml}^{-1}$ of ethidium bromide and then, direct sequencing of the PCR products was done by Hitachi Science System, Ltd. (Tokyo, Japan). The phylogenetic position of the sequences obtained was examined using the DDBJ homology search system BLAST (http://blast.ddbj.nig.ac.jp/topj.html).

The utilization of different carbon sources [acetamide, acetic acid, adonitol, aspartic acid, cellobiose, citric acid, D-arabinose, Dfructose, D-glucose, D-raffinose, dulcitol, glutamic acid, lactose, leucine, lysine, maltose, rhamnose, ribose, sorbitol, sucrose, trehalose, xylitol, and xylose (Wako Pure Chemicals Industries, Ltd.)] was tested using an inorganic salt medium $\left(1.0 \mathrm{~g} \mathrm{NH}_{4} \mathrm{NO}_{3}, 1.0 \mathrm{~g}\right.$ $\mathrm{KH}_{2} \mathrm{PO}_{4}, 0.5 \mathrm{~g} \mathrm{MgSO}_{4}, 0.2 \mathrm{~g} \mathrm{KCl}, 10 \mathrm{~g}$ each carbon source, and $1000 \mathrm{ml}$ distilled water, $\mathrm{pH}$ 7.0).

Fatty acid methyl ester analysis was done using freeze-dried bacterial cells based on the conventional method ${ }^{20)}$. Fatty acid composition was determined by a FID-GC/MS with a 6890 series gas chromatograph and HP 5973 mass selective detector (Hewlett-Packard, Pittsburgh, USA) equipped with a capillary column (DB-23, 0.25 $\mathrm{mm}$ ID $\times 30 \mathrm{~m}, \mathrm{~J} \& \mathrm{~W}$ Scientific) operating with a mass range of $\mathrm{m} / \mathrm{z}$ $50-500$.

\section{Analysis of suppression mechanisms}

\section{(1) Competition for substrates}

BCAs and the bacterial wilt pathogen were co-inoculated into 1 $\mathrm{ml}$ of $1 / 10 \mathrm{NB}$ and glucose or sucrose medium (the ingredients were $1.0 \mathrm{~g} \mathrm{NH}_{4} \mathrm{NO}_{3}, 1.0 \mathrm{~g} \mathrm{KH}_{2} \mathrm{PO}_{4}, 0.5 \mathrm{~g} \mathrm{MgSO}_{4} \cdot 7 \mathrm{H}_{2} \mathrm{O}, 0.2 \mathrm{~g} \mathrm{KCl}, 10 \mathrm{~g}$ glucose or sucrose, and $1000 \mathrm{ml}$ distilled water) at initial densities of $5 \times 10^{7} \mathrm{cfu} \mathrm{ml}^{-1}$ and $5 \times 10^{6} \mathrm{cfu} \mathrm{ml}^{-1}$ for the G5.2rifl strain and at an initial density of $5 \times 10^{4} \mathrm{cfu} \mathrm{ml}^{-1}$ for YU1Rif43. In the control, only the pathogen was inoculated into the media. The population of the pathogen was enumerated by the dilution plate method using $1 / 10$ NA amended with $50 \mu \mathrm{g} \mathrm{mL} \mathrm{m}^{-1}$ each of rifampicin (Wako Pure Chemicals Co.) and of polymyxin B sulfate (Wako Pure Chemicals Co.) after 3 days at $28^{\circ} \mathrm{C}$.

One milliliter of $1 / 10 \mathrm{NB}$ at $28^{\circ} \mathrm{C}$ was co-inoculated with G5.2rifl strain at an initial density of $5 \times 10^{7}$ or $5 \times 10^{6} \mathrm{cfu} \mathrm{ml}^{-1}$ and with the bud-cells of $F$. oxysporum $\mathrm{f}$. sp. lycopersici at an initial density of $10^{5} \mathrm{ml}^{-1}$. After 3 days of incubation at $28^{\circ} \mathrm{C}$, the population of G5.2rif1 strain was enumerated using 1/10 NA amended with $50 \mu \mathrm{g} \mathrm{mL}^{-1}$ of rifampicin and the propagule number of the fungus using Czapeck agar medium amended with $1 \mathrm{~g} \mathrm{~L}^{-1}$ of triton $\mathrm{X}$ 100 (Wako Pure Chemicals Co.) and $300 \mathrm{mg} \mathrm{L}^{-1}$ of streptomycin.

\section{(2) Antibiosis and motility test}

Strains of G4.1rif3 and G5.2rif1 were checked for antibiosis towards the bacterial wilt pathogen YU1Rif43 using a dual culture assay on 1/10 NA. The agar plate was overlaid with $5 \mathrm{ml}$ of $1 / 10$ NB added with $0.025 \mathrm{~g}$ of agar containing $0.1 \mathrm{ml}$ of overnight culture of YU1Rif43 and then the BCAs were spotted on the medium. Inhibition zones were measured after 3 days of incubation at $28^{\circ} \mathrm{C}$. Motility was also tested using a semi-solidified agar $\left(3 \mathrm{~g} \mathrm{~L}^{-1}\right)$ medium poured into petri dishes ${ }^{9}$. BCAs were applied in the middle of the agar plate, and the diameter of the resulting spot was measured at 2-day intervals. 


\section{Disease suppression by $B C A$}

\section{(1) Climatron experiments}

Pumice (100g dry basis) was put into a vinyl pot $9 \mathrm{~cm}$ diameter, inoculated with YU1Rif43 at a density of $5 \times 10^{4} \mathrm{cfu} \mathrm{g}^{-1}$ pumice and supplied with different carbon sources at $0.1 \mathrm{~g}$ (xylose and sucrose) or $0.025 \mathrm{~g}$ (leucine and lysine). In the case of Fusarium diseases, the pumice was inoculated at a density of $10^{5}$ bud-cells $\mathrm{g}^{-1}$ for tomato and at a density of $3 \times 10^{5}$ bud-cells $\mathrm{g}^{-1}$ for spinach. Pumice was added with $\mathrm{CaCO}_{3}$. Then, six two-day-old tomato seeds were transplanted into the pot. The observation and maintenance of the plants were done in the same way as previously described.

(2) Greenhouse experiments

Tomato plants were grown in a greenhouse in two years: the first cultivation was done from September, 2006 to March, 2007 and the second cultivation from February, 2007 to July 2007. The first trial included four treatments: $\mathrm{C}-$ (without the pathogen), $\mathrm{C}+$ (with the pathogen), G5.2rif1 (with the pathogen and strain G5.2rif1), G5.2rif1+sucrose. Twelve two-day-old tomato seeds were transplanted on September 7th, 2006 into a $0.05 \mathrm{~m}^{2}$ pot (1/2000 a Wagner pot, Fujimonoto Science Technology Inc., Japan) containing 3.5 $\mathrm{kg}$ of pumice (equivalent to $7 \mathrm{~L}$ in volume) with $52.5 \mathrm{~g}_{\text {of }} \mathrm{CaCO}_{3}$ and inoculated with strain G5.2rifl and the pathogen at densities of $5 \times 10^{6} \mathrm{cfu} \mathrm{g}^{-1}$ and $5 \times 10^{4} \mathrm{cfu} \mathrm{g}^{-1}$, respectively. The pots were put on a heater mat (Takii Co.) to maintain the temperature in the pumice above $15^{\circ} \mathrm{C}$. The twelve seedlings were thinned to 3 after one month, then to one after two months and cultivated up to 25 weeks after inoculation (WAI). Sucrose was added into each pot at $3.5 \mathrm{~g}$ pot $^{-1}$, equivalent to $1 \mathrm{~g} \mathrm{~kg}^{-1}$ pumice, every two weeks from just after transplanting.

In the second cultivation, three treatments were prepared the same as far the first cultivation, except for G5.2rif1+sucrose. Tomato seeds germinated on February 15th, 2007 in a small biodegradable pot (Jiffy-Garden Series, Sakata Seed Co.) $8 \mathrm{~cm}$ in diameter and containing $100 \mathrm{~g}$ of pumice. For the treatment with G5.2rifl, the bacterium was inoculated into the pot at a rate of $5 \times 10^{6} \mathrm{cfu} \mathrm{g}^{-1}$ at the same day. After seven weeks of cultivation in a greenhouse, the seedlings were transferred on April 5th, 2007 to a $0.05 \mathrm{~m}^{2}$ pot containing $3.5 \mathrm{~kg}$ of pumice added with $52.5 \mathrm{~g}$ of $\mathrm{CaCO}_{3}$ and inoculated with strain G5.2rifl and the pathogen at densities of $5 \times 10^{6}$ cfu $\mathrm{g}^{-1}$ and $5 \times 10^{4} \mathrm{cfu} \mathrm{g}^{-1}$, respectively. For each treatment, five replicate pots containing two plants were prepared. After 3 weeks, two plants per pot were thinned to 1 plant and then cultivated up to 13 weeks after transplanting (WAT).

Watering was done using the Otsuka liquid fertilizer A formula two times a day to adjust the water content to around pF2. Fifty percent of the concentration of the liquid fertilizer was used until the first flowering and then $75 \% \mathrm{t}$ until the initial enlargement of fruits. The disease incidence was monitored every week and biocontrol efficacy was calculated using the following formula: biocontrol efficacy $=($ disease incidence of control- disease incidence of treatment group]/disease incidence of control) $\times 100$. At harvest, the quality and quantity of tomato fruits were determined.

(3) Measurement of tomato quality

Electric conductivity (EC) and sugar and vitamin C contents of the tomato flesh were determined to evaluate tomato quality. Slices of tomato fruit $(3.0 \mathrm{~g})$ were mixed with $15 \mathrm{ml}$ of distilled water. After vigorous shaking for one minute on a Vortex-Genie 2 (M\&S Instruments Inc., Tokyo, Japan), EC values were measured by a Twin Compact Meter (Horiba Ltd., Kyoto, Japan). For the determination of sugar content, one drop of the tomato homogenate was put on the prism of a Hand Refractometer (N-10E type, Atago Co. Ltd., Tokyo, Japan). For the determination of vitamin C, $10.0 \mathrm{~g}$ of the tomato flesh was added to $10 \mathrm{ml}$ of $5 \%$ metaphosporic acid (Wako Pure Chemicals Industries, Ltd.) and homogenized by a Mill mixer FM-50 (Sun Co., Osaka, Japan). An aliquot $(1.0 \mathrm{ml})$ of the homogenate was dispensed into a $1.5 \mathrm{ml}$ tube and centrifuged at $15000 \mathrm{xg}$ for 1 minute and the supernatant was used for the determination of vitamin $\mathrm{C}$ using the vitamin $\mathrm{C}$ test kit (Merck, Germany) with a reflectometer RQflex plus 10 (Merck, Germany). The measurements were done in six and five replicates in the 2006 and 2007 cultivations, respectively, which consisted of one to four tomato fruits per replicate.

\section{Results}

Screening and characterization of biocontrol agents for bacterial wilt of tomato

In the first screening, 54 combinations each of which contained 5 strains were tested for bacterial wilt of tomato and 9 combinations showed more than $50 \%$ reduction of disease incidence. In the second screening, individual strains were tested and 6 out of 45 strains suppressed bacterial wilt of tomato significantly (less than $50 \%$ of disease index (DI), Table 1). Since it was found that the C13, G4 and G5 strains were mixtures of two strains, they were carefully purified again and further tested for the ability to suppress disease. In the third and fourth screenings, three and six isolates suppressed DI by more than $50 \%$, respectively.

Some properties of the strains C13.1, G4.1, G5.1 and G5.2 were shown (Table 2) and they were nearest to Burkholderia sacchari, Burkholderia pyrrocinia, Burkholderia terricola and Burkholderia nodosa (Fig. 1)

The following substrates are utilized by C13.1: adonitol, cellobiose, citric acid, D-arabinose, D-fructose, D-glucose, D-raffinose, D-xylose, lactose, leucine, lysine, maltose, rhamnose, sorbitol, sucrose and xylitol. The following carbon sources are not utilized: acetamide, acetic acid, aspartic acid, dulcitol, glutamic acid, ribose and trehalose. Strain G4.1 showed the following substrate utilization profile: positive (acetamide, adonitol, cellobiose, D-arabinose, D-fructose, D-glucose, D-raffinose, dulcitol, D-xylose, lactose, leucine, lysine, maltose, sorbitol, sucrose, trehalose and xylitol) and negative (acetic acid, aspartic acid, citric acid, glutamic acid, rhamnose and ribose). Strain G4.2 had quite a similar profile to G4.1 (data not shown). Strain G5.1 utilized adonitol, cellobiose, D-glucose, D-raffinose, rhamnose, sorbitol, sucrose and xylitol and but not acetamide, acetic acid, aspar-

Table 1. Suppression of bacterial wilt of tomato by BCAs isolated from Kalimantan soils.

\begin{tabular}{lccc}
\hline \multirow{2}{*}{ Screening times } & \multicolumn{3}{c}{ Disease index } \\
\cline { 2 - 4 } Control+ & $2^{\text {nd }}$ & $3^{\text {rd }}$ & $4^{\text {th }}$ \\
C12 & $100 \mathrm{a}$ & $97 \mathrm{a}$ & $61 \mathrm{a}$ \\
C13 & $35 \mathrm{~b}$ & $47 \mathrm{c}$ & $28 \mathrm{ab}$ \\
C13.1 & $17 \mathrm{~b}$ & - & - \\
C13.2 & - & $61 \mathrm{~b}$ & $11 \mathrm{~b}$ \\
E20 & - & $69 \mathrm{~b}$ & $38 \mathrm{ab}$ \\
G3 & $19 \mathrm{~b}$ & $68 \mathrm{~b}$ & $39 \mathrm{ab}$ \\
G4 & $21 \mathrm{~b}$ & $81 \mathrm{a}$ & $39 \mathrm{ab}$ \\
G4.1 & $22 \mathrm{~b}$ & - & - \\
G4.2 & - & $65 \mathrm{~b}$ & $6 \mathrm{~b}$ \\
G5 & - & $36 \mathrm{c}$ & $11 \mathrm{~b}$ \\
G5.1 & $40 \mathrm{~b}$ & - & - \\
G5.2 & - & $38 \mathrm{c}$ & $13 \mathrm{~b}$ \\
\hline
\end{tabular}

Disease index at $30 \mathrm{~d}$ after inoculation is shown: 0, all healthy, 100: all dead. Values with the same letters are not significantly different $(\mathrm{P}=0.05)$ according to the protected Fisher's LSD test. 
Tabel 2. Identification of biocontrol agents and analysis of the suppression mechanisms.

\begin{tabular}{|c|c|c|c|c|c|c|}
\hline Strain & Identification a & Similarity & Origin & Antibiosis & Competition & Motility \\
\hline C13.1 & Burkholderia sacchari & $100 \%$ & Agricultural peat & - & nd & $\mathrm{nm}$ \\
\hline G4.1 & B. pyrrocinia & $100 \%$ & Burn forest & + & + & $\mathrm{m}$ \\
\hline G4.2 & nd & nd & Burn forest & + & + & $\mathrm{m}$ \\
\hline G5.1 & B. terricola & $100 \%$ & Burn forest & - & + & $\mathrm{nm}$ \\
\hline G5.2 & B. nodosa & $100 \%$ & Burn forest & - & + & $\mathrm{m}$ \\
\hline
\end{tabular}

a, identification according to $16 \mathrm{SrDNAsequencing}$ and fatty acid analysis.

$\mathrm{Nd}$, not determined; $\mathrm{m}$, motile; nm, nomotile; +, antibiosis/competition; -, noantibiosis/competition

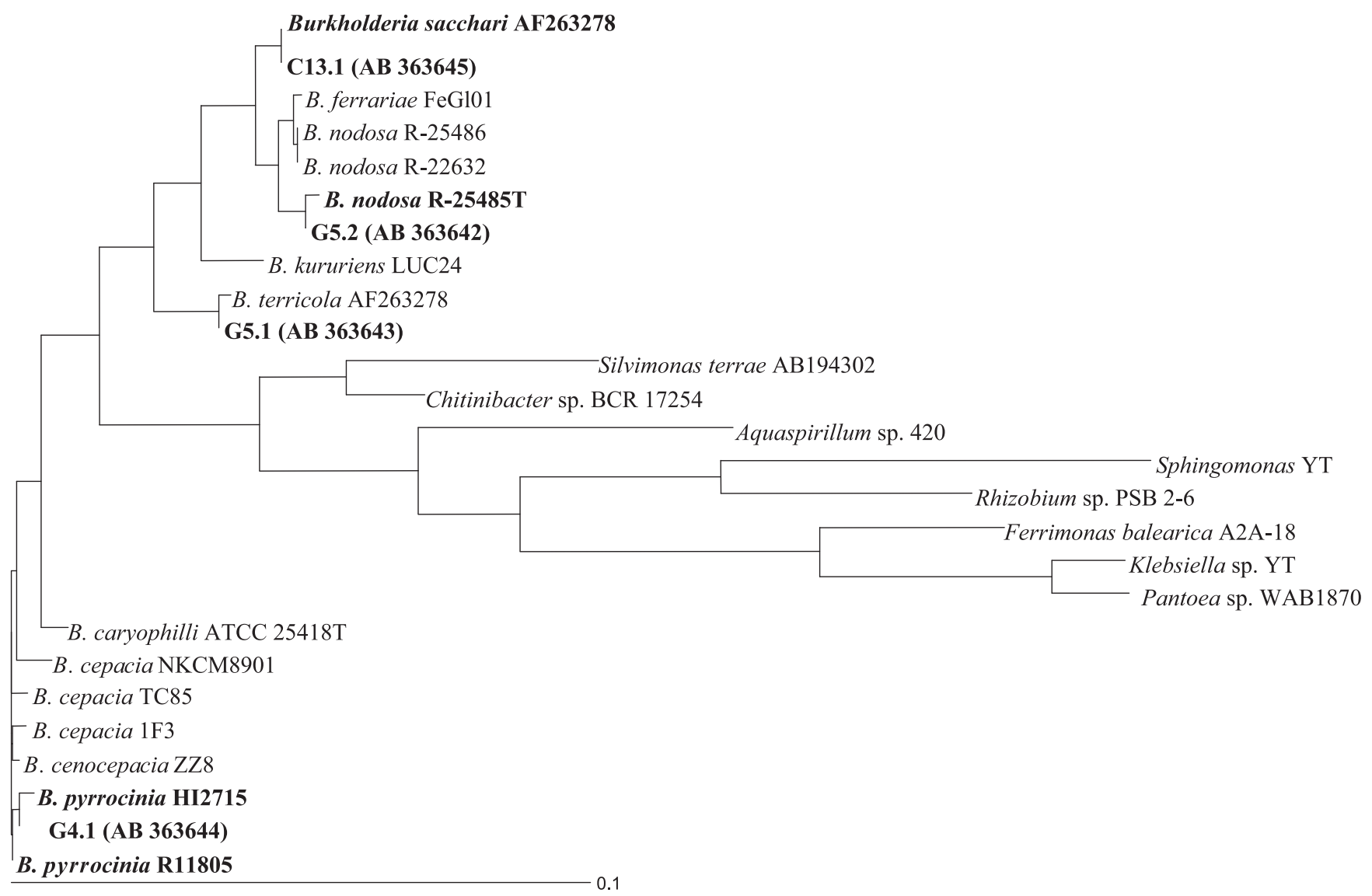

Fig. 1. Phylogenic tree based on the $16 \mathrm{~S}$ rDNA gene sequence analysis of peat soil bacteria scale bare indices $10 \%$ sequences divergence. Strain names are preceded by their Gen Bank accession numbers and the date of sample collection is written in parentheses. DNA sequences of some control strains were obtained from the DDBJ database.

Table. 3. Competition between B. nodosa G5.2rif1 and R. solanacearum YU1Rif43 in different media (nutrient broth, glucose and sucrose media).

\begin{tabular}{cccc}
\hline \multirow{2}{*}{ Treatment } & \multicolumn{3}{c}{ Population density of YU1Rif43 after 3 d incubation in } \\
\cline { 2 - 4 } & Nutrient broth $\left(\times 10^{8} \mathrm{cfu} \mathrm{ml}^{-1}\right)$ & Glucose $\left(\times 10^{6} \mathrm{cfu} \mathrm{m}^{-1}\right)$ & Sucrose $\left(\times 10^{7} \mathrm{cfu} \mathrm{m}^{-1}\right)$ \\
\hline Pathogen alone $\left(5 \times 10^{4} \mathrm{cfu} \mathrm{ml}^{-1}\right)^{*}$ & $5.6 \mathrm{a}$ & $2.7 \mathrm{a}$ & $5.4 \mathrm{a}$ \\
Pathogen+G5.2rif1 $\left(5 \times 10^{7} \mathrm{cfu} \mathrm{ml}^{-1}\right)$ & $1.6 \mathrm{~b}$ & $0.1 \mathrm{~b}$ & $2.5 \mathrm{~b}$ \\
Pathogen+G5.2 $\left.\left(5 \times 10^{6} \mathrm{cfu} \mathrm{m}\right)^{-1}\right)$ & $2.3 \mathrm{~b}$ & $0.4 \mathrm{~b}$ & $4.3 \mathrm{~b}$ \\
\hline
\end{tabular}

*( ) : the initial density of the isolate. Values with the same letters are not significantly different $(\mathrm{P}=0.05)$ according to the protected Fisher's LSD test.

tic acid, citric acid, D-arabinose, sucrose, dulcitol, D-xylose, glutamic acid, lactose, leucine, lysine, maltose, ribose and trehalose. The following substrates were utilized by strain G5.2: cellobiose, D-arabinose, D-glucose, D-raffinose, D- xylose, lactose, leucine, lysine, maltose, rhamnose, sorbitol, sucrose, trehalose and xylitol, while the following were not utilized: acetamide, acetic acid, adonitol, aspartic acid, citric acid, D-fructose, dulcitol, glutamic acid and ribose. 
Table. 4. Competition between B. nodosa G5.2rifl and F. oxysporum f.sp. lycopersici $880621 \mathrm{a}$, race 2 (FOL) in nutrient broth.

\begin{tabular}{cc}
\hline Treatment & $\begin{array}{c}\text { Population density of FOL after } \\
3 \mathrm{~d} \text { incubation }\left(\times 10^{3} \mathrm{cfu} \mathrm{m}^{-1}\right)\end{array}$ \\
\hline FOL alone $\left(10^{5} \mathrm{cell} \mathrm{m}^{-1}\right)^{*}$ & $80 \mathrm{a}$ \\
FOL+G5.2 $\left(5 \times 10^{7} \mathrm{cfu} \mathrm{ml}^{-1}\right)$ & $6 \mathrm{~b}$ \\
FOL+G5.2 $\left(5 \times 10^{6} \mathrm{cfu} \mathrm{ml}^{-1}\right)$ & $8 \mathrm{a}$ \\
\hline
\end{tabular}

*( ): the initial density. Values with the same letters are not significantly different $(\mathrm{P}=0.05)$ according to the protected Fisher's LSD test.

Table 5. Effect of B. nodosa G5.2rifl and carbon sources on the disease index of bacterial wilt of tomato, and Fusarium wilt of tomato and spinach in small-pot experiments.

\begin{tabular}{|c|c|c|c|c|c|}
\hline & \multicolumn{2}{|c|}{ BWT } & \multirow{2}{*}{$\frac{\text { FWT }}{1 \mathrm{st}^{\mathrm{z}}}$} & \multicolumn{2}{|c|}{ FWS } \\
\hline & $1 \mathrm{st}^{\mathrm{x}}$ & $2 \mathrm{nd}^{\mathrm{x}}$ & & $1 \mathrm{st}^{\mathrm{x}}$ & $2 n d^{y}$ \\
\hline Control+(Pathogen alone) & $65 a$ & $67 \mathrm{a}$ & $83 a$ & $50 \mathrm{a}$ & $78 \mathrm{a}$ \\
\hline$+\mathrm{G} 5.2 \mathrm{rif1}$ & $11 \mathrm{~b}$ & $44 b$ & $24 b$ & $47 b$ & \\
\hline +Sucrose & $61 \mathrm{a}$ & & & & \\
\hline +G5.2rif1+sucrose & $6 \mathrm{~cd}$ & $0 b$ & $89 a$ & & \\
\hline +G5.2rif1+leucine & $33 b$ & & & & \\
\hline +G5.2rif1+lysine & $15 b c$ & & & & \\
\hline +G5.2rif1+xylose & $17 \mathrm{bc}$ & & & & \\
\hline
\end{tabular}

BWT=bacterial wilt of tomato; $\mathrm{FWT}=$ Fusarium wilt of tomato; FWS $=$ Fusarium wilt of spinach. Disease index are the values at $x=30 \mathrm{~d}$ after inoculation (dai); $\mathrm{w}=24$ dai; $\mathrm{y}=40$ dai and $\mathrm{z}=46$ dai. Values with the same letters are not significantly different $(\mathrm{P}=0.05)$ according to the protected Fisher's LSD test. $1^{\text {st }}$ and $2^{\text {nd }}$ indicate repeated experiments.

Strain C13.1 showed C16:0 (29.4\%), C16:1 (29.6), C17:0 cyclo (3.5\%), C18: $1 \omega 7 \mathrm{c}(20.5 \%)$, and $\mathrm{C} 19: 0 \omega 8 \mathrm{c}$ cyclo (3.9\%). Strain G4.1 showed C14:1 (18.1\%), C14:0-3OH (5.9\%), C16:0 (31.5\%), C16:1 (19.6\%), C18:0 (1.5\%), C18: $1 \omega 7 \mathrm{c}(14.3 \%)$, and $\mathrm{C} 19: 0 \omega 8 \mathrm{c}$ cyclo $(3.3 \%)$. Strain G5.1 showed C14:0 3OH (5.5\%), C14.1 (24.7\%), C16:0 (22.4\%),

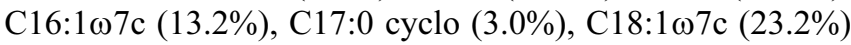
and C19:0 $\omega 8$ c cyclo (3.7\%). Strain G5.2 showed C14:0 3$\mathrm{OH}$ (7.7\%), C16:0 (41.5\%), C16:1 (22.4\%), C17:0 cyclo (2.9\%), C18: $1 \omega 7 \mathrm{c}(19.6 \%)$ and $\mathrm{C} 19: 0 \omega 8 \mathrm{c}$ cyclo $(3.6 \%)$.

\section{Competition for substrates}

When $R$. solanacearum YU1Rif43 was inoculated into 1/ $10 \mathrm{NB}$, glucose and sucrose media simultaneously with $B$. nodosa G5.2rif1, the population of YU1Rif43 significantly
Table 6. Effect of B. nodosa G5.2rif1 and sucrose on the disease index of bacterial wilt of tomato and population density of the BCA and the pathogen in a small-pot experiment

\begin{tabular}{lccc}
\hline \multirow{2}{*}{ Treatment } & Disease index & \multicolumn{2}{c}{$\begin{array}{c}\text { Population density of } \\
\text { (log cfu g-1 }\end{array}$} \\
\cline { 3 - 4 } & & YU1Rif43 & G5.2rif1 \\
\hline Control+(Pathogen alone) & $100 \mathrm{a}$ & $8.6 \mathrm{a}$ & - \\
+G5.2rif1 & $67 \mathrm{ab}$ & $5.3 \mathrm{~b}$ & $4.7 \mathrm{~b}$ \\
+Sucrose & $89 \mathrm{a}$ & $8.6 \mathrm{a}$ & - \\
+G5.2rif1+sucrose & $50 \mathrm{~b}$ & $6.4 \mathrm{~b}$ & $6.4 \mathrm{a}$ \\
\hline
\end{tabular}

Disease index was measured at 30 days after seeding/inoculation and the population density at 24 days. Values with the same letters are not significantly different $(\mathrm{P}=0.05)$ according to the protected Fisher's LSD test.

decreased in the presence of the competitor (Table 3). The number of $F$. oxysporum f. sp. lycopersici 880621 a also significantly decreased in the presence of B. nodosa G5.2rif1 (Table 4).

\section{Biocontrol ability of $B C A$}

When carbon sources (sucrose, xylose, leucine and lysine) were added into a pumice medium in combination with $B$. nodosa G5.2rif1, addition of all the substrates markedly decreased BWT (Table 5). The combination with sucrose was most effective and the efficacy was confirmed a further two times ( $2^{\text {nd }}$ in Table 6 and Table 7$)$. The population density of the pathogen was significantly lower in the presence of $B$. nodosa G5.2rif1, while the population density of $B$. nodosa G5.2rif1 was higher with sucrose (6.4 log cfu g-1 root) than on single inoculation $\left(4.7 \log \mathrm{cfu}^{-1} \mathrm{root}\right.$ ) (Table $6)$. In contrast, the combination of sucrose and $B$. nodosa G5.2rif1 did not suppress FWS, while the single inoculation of $B$. nodosa G5.2rifl significantly suppressed FWS (Table $5)$.

In the greenhouse experiments, no inhibitory effects were found on the growth, yield and quality of tomato for a single inoculation of G5.2rif1 or a combination of $B$. nodosa G5.2rif1 with sucrose (Table 7). In 2006, the tomato yield was approximately $1600 \mathrm{~g} \mathrm{plant}^{-1}$ in the control,$- B$. nodosa G5.2rif1 and B. nodosa G5.2rif1+sucrose treatments, while it was only $800 \mathrm{~g} \mathrm{plant}^{-1}$ in the control+treatment and the differences were highly significant. This result was confirmed in the 2007 greenhouse experiment, in which tomato yield

Table 7. Effect of B. nodosa G5.2riflon the disease index of bacterial wilt of tomato and quality of tomato fruit in greenhouse experiments

\begin{tabular}{|c|c|c|c|c|c|c|}
\hline Treatment & Disease index & Height* (cm) & Yield (g/plant) & $\mathrm{EC}(\mathrm{mS} / \mathrm{cm})$ & Sugar $(\%)$ & Vit. C (mg/100g fruit) \\
\hline \multicolumn{7}{|c|}{ First time cultivation 2006 Sep to $2007 \mathrm{Mar}$} \\
\hline No pathogen (Control-) & $0 \mathrm{c}$ & 171 & $1557 \mathrm{a}$ & 1.1 & 7.1 & 34 \\
\hline Control+(Pathogen alone) & $62 \mathrm{a}$ & 153 & $883 \mathrm{~b}$ & 1.0 & 7.3 & 33 \\
\hline$+\mathrm{G} 5.2 \mathrm{rifl}$ & $42 \mathrm{~b}$ & 134 & $1783 \mathrm{a}$ & 1.2 & 7.5 & 33 \\
\hline$+\mathrm{G} 5.2$ rif1+sucrorse & $13 \mathrm{c}$ & 172 & $1351 \mathrm{a}$ & 1.1 & 7.4 & 33 \\
\hline \multicolumn{7}{|c|}{ Second time cultivation $2007 \mathrm{Feb}$ to $2007 \mathrm{Jul}$} \\
\hline No pathogen & $0 \mathrm{c}$ & 119 & 849 a & 1.5 & 7.9 & 26 \\
\hline Control+ & $35 \mathrm{a}$ & 116 & $347 \mathrm{~b}$ & 1.6 & 8.4 & 26 \\
\hline$+\mathrm{G} 5.2 \mathrm{rif1}$ & $10 \mathrm{~b}$ & 122 & $675 \mathrm{a}$ & 1.6 & 8.7 & 25 \\
\hline
\end{tabular}

EC, electric conductivity; Vit., vitamin C; $*$ at 25 and 13 weeks after transplanting in 2006 and 2007, respectively. Values with the same letters are not significantly different $(\mathrm{P}=0.05)$ according to the protected Fisher's LSD test. 
was about $760 \mathrm{~g} \mathrm{plant}^{-1}$ in the control - and B. nodosa G5.2rif1 treatments, but $340 \mathrm{~g} \mathrm{plant}^{-1}$ in the control+treatment. In the measurement of the quality of tomato, there were no significant differences in the EC values, or sugar and vitamin $\mathrm{C}$ contents of tomato fruits among the control,$- B$. nodosa G5.2rif1 and B. nodosa G5.2rif1+sucrose treatments in either year.

\section{Discussion}

Among 270 crystal violet tolerant bacterial isolates from soils of Kalimantan, Indonesia, five strains (C13.1, G4.1, G4.2, G5.1 and G5.2) showed good suppression of bacterial wilt of tomato caused by $R$. solanacearum in small pot experiments. The strains C13.1, G4.1, G5.1 and G5.2 were phylogenetically closest to Burkholderia sacchari, B. pyrrocinia, B. terricola, and B. nodosa, respectively. We checked by $16 \mathrm{~S}$ rDNA sequences in 4 species but we did not sequence one isolate (G4.2), because in term of colony and substrate utilization of G4.1 and G4.2 isolates were similar. Fatty acid methyl ester profiles of strains C13.1, G4.1, G5.1 and G5.2 were compared with those of related Burkholderia species such us B. sacchari $^{4)}$, B. pyrrocinia ${ }^{32)}$, B. terricola ${ }^{11)}$, B. nodosa ${ }^{6)}$, B. ferrariae ${ }^{38)}$, B. unamae ${ }^{5)}$ and B. kururiensis ${ }^{44)}$. The fatty acid profiles of strains C13.1, G4.1 and G5.1 were similar to those of B. sacchari, B. pyrrocinia and B. terricola, respectively. Strain G5.2 was phylogentically closest to $B$. nodosa, but it was also close to B. ferrariae (Fig. 1). C17:0 cyclo is major fatty acid in $B$. ferrariae ${ }^{38}$, but not in $B$. nodos $a^{6}$. Thus, the fatty acid profile of strain G5.2 was considered to be more similar to that of $B$. nodosa. Carbon source utilization patterns supported these identifications: $70 \%$ homology between G5.2 and B. nodosa, 27\% between G5.2 and B. ferrariae, 71\% between G5.1 and B. terricola, $85 \%$ between G4.1 and B. pyrrocinia, and $60 \%$ between C13.1 and B. sacchari.

de Souza and Raaijmakers ${ }^{8)}$ reported that B. pyrrocinia produces pyrrolnitrin which is a broad spectrum and chlorinated phenylpyrrole antibiotic first isolated from B. pyrrocinia. In this study, B. pyrrocinia G4.1 also showed antibiosis against $R$. solanacearum. B. pyrrocinia belongs to the $B$. cepacia complex and $B$. cepacia has been recognized as an important opportunistic human pathogen, especially among cystic fibrosis patients ${ }^{30}$, although strains belonging to $B$. cepacia have often been identified as $\mathrm{BCAs}^{33)}$. B. pyrrocinia and $B$. terricola have the ability to suppress plant disease $24,25)$. But there are no reports for the remaining 2 species $B$. sacchari, and $B$. nodosa as biocontrol agents. Goris et al. ${ }^{11)}$ reported that a bacterium belonging to $B$. terricola has genes for degrading 2,4-dichlorophenoxyacetic acid (2,4-D). Brämer et $a l .{ }^{4)}$ reported that $B$. sacchari strain IPT101, isolated from a sugar-cane plantation soil in Brazil, was a producer of polyhydroxyalkanoates from sucrose and other carbon sources. Burkholderia nodosa, a new member of the genus Burkholderia, was originally isolated from woody legumes native in Brazil ${ }^{6}$. In some culture collections, such as American Type Culture Collection, (ATTC), Collection de I'Institut Pasteur (CIP) and Deutsche Sammlung Von Mikroorganimen und Zellkulturen (DSMZ), all strains belonging to the species $B$. sacchari, B. terricola and $B$. nodosa were originally isolated from soil but none from medical specimens, suggesting the potential application of these species in fields. For further experiments, strain G5.2 was selected and a rifampicin resistant mutant was obtained, since strain G4.1 which also showed good suppression of BWT like G5.2 belonged to the Burkholderia cepacia complex.

The inoculation of B. nodosa G5.2rif1 into a pumice medium decreased the wilt symptoms of not only BWT, but also FST and FSW (Table 1 and Table 5). The reduction of bacterial wilt by $B$. nodosa G5.2rif1 was $33-84 \%$ in the climatron experiments. The protective effects of this BCA were almost the same as in previous reports, e.g. BCAs reduced the disease in banana, eggplant and tomato by $36-95 \%{ }^{2)}$, in tomato by $66-94 \%{ }^{12)}$, and $27-82 \%^{45}$. We further tested the efficacy of B. nodosa G5.2rif to BWT in greenhouse experiments, in which $B$. nodosa G5.2rif1 significantly increased the yield of tomato both in 2006 and 2007 experiments and significantly decreased BWT in 2007, compared to that in the control inoculated with the pathogen alone (Table 8). Since $B$. nodosa G5.2rif1 did not have any negative effect on plant height and sugar content and EC value of the tomato fruits, it was considered a good biocontrol agent.

Burkholderia nodosa G5.2rif1 did not show inhibition of to $R$. solanacearum and $F$. oxysporum $\mathrm{f}$. sp. lycopersici 880621 a (Table 2), suggesting that antibiosis was not involved in the suppression. Kamilova et al. ${ }^{17)}$ reported that Pseudomonas fluorescens 1751 which does not possess antifungal activities, such as lipase, $\beta$-glucanase, cellulase, chitinase, autoinducer, biosurfactant, hydrogen cyanide, and indole-3-acetic acid, reduced root rot symptoms caused by $F$. oxysporum f. sp. radicis-lycopersici through competition for nutrients and niches. In this study, the population density of $R$. solanacearum YU1Rif43 was significantly decreased by the co-inoculation of $B$. nodosa G5.2rifl into all the media used (1/10 NB, glucose and sucrose media) (Table 3), suggesting that competition for nutrients was at least one of the main mechanisms by which G5.2rif1 suppressed bacterial wilt disease. Suppression of plant diseases through competition for nutrients between BCA and a pathogen has been reported. Van Dijk and Nelson ${ }^{39)}$ reported that Enterobacter cloacae suppressed Pythium ultimum sporangium germination and damping-off through competition for nutrients. Kamilova et al. ${ }^{18)}$ found that a BCA, Collimonas fungivorans, controlled tomato foot and root rot (TFRR) mainly through competition for nutrients and niches, rather than mycophagous activity. In this study, the contribution of induced systemic resistance was not tested as a suppressive mechanism of strain G5.2rif1 and thus remains to be further evaluated.

In this study, to enhance the suppressive properties of the BCAs, different kinds of organic compounds were selected based on two criteria; utilizability by the BCAs but not by the pathogen and economical considerations. The addition of leucine, lysine, xylose (substrates not utilized by the pathogen) or sucrose (utilizable by the pathogen), along with $B$. nodosa G5.2rif1, markedly suppressed BWT (Table 5). Among them, the sucrose treatment was the most suppressive, although the addition of sucrose alone was not suppressive, suggesting that $B$. nodosa G5.2rif1 utilized sucrose more efficiently and developed its population and thereby 
suppressed BWT. The efficacy of sucrose in combination with $B$. nodosa G5.2rif1 was further confirmed in a greenhouse experiment (Table 7), in which a significant reduction of disease incidence was observed with G5.2rif1+sucrose compared to that obtained with a single inoculation of G5.2rif1. In contrast, a combination of B. nodosa G5.2rif1 with sucrose did not show enhanced suppression for FWT and FWS (Table 5). Hoffland et al. ${ }^{13)}$ explained that disease susceptibility is highly pathogen-specific and is probably dependent on differences in resource requirements of the pathogen, or the sensitivity of the pathogen to plant resistance reactions, or both these factors.

\section{Acknowledgements}

YAN expresses great thanks to the Ministry of Education, Science, Sports and Culture of Japan for the scholarship. The authors also express sincere thanks to Dr. S. Matsumura, for useful advice on tomato cultivation and for lending them the greenhouse, to $\mathrm{Mr} \mathrm{T}$. Igawa for his help in tomato cultivation, Dr. Y. Takahara for useful discussions, Dr. T. Arie for the gift of Fusarium oxysporum f. sp. lycopersici 880621a, and Dr. Y. Amemiya for the gift of $F$. oxysporum f. sp. spinaciae GF-2. The pumice used in this study was provided by Ebara Corp. (1-6-27, Kohnan, Minato, Tokyo 1088480 ), along with a cultivation manual. This work was supported by a Research project (No. 1765) for utilizing advanced technologies in agriculture, forestry and fisheries.

\section{References}

1) Agrios, G.N. 2005. Plant pathology. (5 $5^{\text {th }}$ Ed.). Academic Press, San Diego, USA.

2) Anuratha, C.S., and S.S. Gnanamanickam. 1990. Biological control of bacterial wilt caused Pseudomonas solanacearum in India with antagonistic bacteria. Plant Soil 124:109-116.

3) Artiningsih, T., S.H. Tuah, E. Mirmanto, and M. Osaki. 2000. Survey of peat soils in Sebangau-Kahayan for laccase producing fungi and their organic decomposing ability, p. 61-67. In Proceeding of the International Symposium on Tropical Peatlands, Bogor, Indonesia, 22-23 November 1999.

4) Brämer, C.O., P. Vandamme, L.F. da Silva, J. Gregório, C. Gomez, and A. Steinbüchel. 2001. Burkholderia sacchari sp. nov., a polyhydrooxylakanoate-accumulating bacterium isolated from soil of a sugar-cane plantation in Brazil. Int. J. Syst. Evol. Microbiol. 51:1709-1713.

5) Caballero-Mellado, J., L. Martinez-Aguilar, G. Parades-Valdez, and P. E. de los Santos. 2004. Burkholderia unamae sp. nov., an $\mathrm{N}_{2}$-fixing rhizospheric and endophytic species. Int. J. Syst. Evol. Microbiol. 54:1166-1172.

6) Chen, W., S.M. de Faria, E.K. James., G.N. Elliott, K. Lin, J. Chou, S. Sheu, M. Cnockaert, J.I. Sprent, and P. Vandamme. 2007. Burkholderia nodosa sp. nov., isolated from root nodules of the woody Brazilian legumes Mimosa bimucronata and Mimosa scabrella. Int. J. Syst. Evol. Microbiol. 57:1055-1059.

7) Cook, R.J., and K.F. Baker. 1983. The nature and practice of biological control of plant pathogens. APS Press, Minnesota, USA.

8) de Souza, J.T., and J.M. Raaijmakers. 2003. Polymorphisms within the $\operatorname{prnD}$ and pltC genes from pyrrolnitrin and pyoluterin-producing Pseudomonas and Burkholderia spp. FEMS Microbiol. Ecol. 43:2134.

9) de Weert, S., H. Vermeiren, I.H.M. Mulders, I. Kuiper, N. Hendrickx, G.V. Bloemberg, J. Vanderleyden, R. de Mot, and B.J.J. Lugtenberg. 2002. Flagella-driven chemotaxis towards exudate components is an important trait for tomato root colonization by Pseudomonas fluorescens. Mol. Plant-Microbe Interact. 15:1173-1180.

10) Dhingra, O.D., and J.B. Sinclair. 1995. Basic plant pathology method ( $2^{\text {nd }}$ ed.). CRC Press, Florida, USA.

11) Goris, J, W. Dejonghe, E. Falsen, E. de Clerck, B. Geeraerts, A. Willems, E.M. Top, P. Vandamme, and P. de Vos. 2002. Diversity of transconjugants that acquired plasmid pJP4 or pEMT1 after inoculation of a donor strain in the A- and B-horizon of an agricultural soil and description of Burkholderia hospital sp. nov. and Burkholderia terricola sp. nov. System. App. Microbiol. 25:340-352.

12) Guo, J-H., H. Qi, Y. Guo, H. Ge, L. Zhang, L. Gong, and P. Sun. 2004. Biocontrol of tomato wilt by plant growth-promoting rhizobacteria. Biol. Control 29:66-72.

13) Hoffland, E., M.J. Jeger, and M.L. van Beusichem. 2000. Effect of nitrogen supply rate on disease resistance in tomato depends on the pathogen. Plant Soil 218:239-247.

14) Holding, A.J. 1954. The predominant gram-negative bacteria in soil. J. Appl. Bact. 17:16.

15) Irikiin, Y., M. Nishiyama, S. Otsuka, and K. Senoo. 2006. Rhizobacterial community-level, sole carbon source utilization pattern affects the delay in the bacterial wilt of tomato grown in rhizobacterial community model system. Appl. Soil Ecol. 34:27-32.

16) Islam, T. MD., and K. Toyota. 2004. Suppression of bacterial wilt of tomato by Ralstonia solanacearum by incorporation of composts in soil and possible mechanisms. Microbes Environ. 19:53-60.

17) Kamilova, F, S. Validov, T. Azarova, I. Mulders, and B. Lugtenberg. 2005. Enrichment for enhanced competitive plant root tip colonizers selects for a new class of biocontrol bacteria. Environ. Microbiol. 7:1809-1817.

18) Kamilova, F, J.H.J. Leveau, and B. Lugtenberg. 2007. Collimonas fungivorans, an unpredicted in vitro but efficient in vivo biocontrol agent for the suppression of tomato foot and root rot. Environ. Microbiol. 9:1597-1603.

19) Kaur, J., G.D. Munshi, R.S. Singh, and E. Koch. 2005. Effect of carbon source on production of lytic enzymes by the sclerotial parasites Trichoderma atroviride and Coniothyrium minitans. J. Phytopathol. 153:274-279.

20) Komagata, K. (ed.) 1982. Biseibutunokagakujikkenbunruihou. Gakkai Shuppan Center, Tokyo.

21) Lane, D.J., B. Pace, G.J. Olsen, D.A. Stahl, M.L. Sogin, and N.R. Pace. 1985. Rapid determination of 16S rRNA sequences for phylogenetic analysis. Proc. Natl. Acad. Sci. USA 82:6955-6959.

22) Miyashita, K. 1992. DNA probe method, p. 162-172. In Nihon jojobiseibutsu kenkyukai (ed.), Dojyobiseibutsujikkenhou. Yokendo, Tokyo, Japan. (in Japanese)

23) Montesinos, E. 2003. Development, registration and commercialization of microbial pesticides for plant protection. Int. Microbiol. 6:245-252.

24) Opelt, K., and G. Berg. 2004. Diversity and antagonistic potential of bacteria associated with bryophytes from nutrient-poor habitats of the Baltic sea coast. Appl. Environ. Microbiol. 70: 6569-6579.

25) Opelt, K., C. Berg, and G. Berg. 2007. The bryophyte genus Sphagnum is a reservoir for powerful and extraordinary antagonist and potentially facultative human pathogens. FEMS Microbiol. Ecol. 6:38-53.

26) Posas, M.B., K. Toyota, and T.MD. Islam. 2007. Inhibition of bacterial wilt of tomato caused by Ralstonia solanacearum by sugars and amino acids. Microbes Environ. 22:290-296.

27) Purnomo, E., A. Mursyid, M. Syarwani, A. Jumberi, Y. Hashidoko, T. Hasegawa, S. Honma, and M. Osaki. 2005. Phosphorus solubilizing microorganisms in the rhizosphere of local rice varieties grown without fertilizer on acid sulfate soils. Soil Sci. Plant Nutr. 61:679681.

28) Purwaningsih, S., T. Artiningsih, and M. Osaki. 2000. Characterization and population of nitrogen-fixing bacteria from peat soil in Kahayan water-catchment, Central Kalimantan, p. 287. In Proceeding of the International Symposium on Tropical Peatlands, Bogor, Indonesia, 22-23 November 1999.

29) Smith, J.L., and H.P. Collins. 2007. Management of organisms and their processes in soils, p. 471-502. In E.A. Paul (ed.), Soil microbiology, ecology, and biochemistry, $3^{\text {rd }}$ Ed. Academic Press, Burlington, MA, USA.

30) Storms, V., N. Van Den Vreken, T. Coenye, E. Mahenthiralingam, J.J. LiPuma, M. Gillis, and P. Vandamme. 2004. Polyphasic characterization of Burkholderia cepacia-like isolates leading to the emended description of Burkholderia pyrrocinia. System. Appl. Microbiol. 27:517-526.

31) Stotzky, G. 1997. Soil as environment for microbial life, p. 1-20. In J.D. van Elsas, J.T. Trevors, and E.M.H. Wellington (ed). Modern soil microbiology. Marcell Dekker, New York, USA. 
32) Tabacchioni, S., A. Bevivino, C. Dalmastri, and L. Chiarini. 2002. Burkholderia cepacia complex in the rhizosphere: a minireview. Annu. Rev. Microbiol. 52:103-117.

33) Takakai, F., T. Morishita, Y. Hashidoko, U. Darung, K. Kuramochi, S. Dohong, S.H. Limin, and R. Hatano. 2006. Effects of agricultural land-use change and forest fire on $\mathrm{N}_{2} \mathrm{O}$ emissions from tropical peatlands, Central Kalimantan, Indonesia. Soil Sci. Plant Nutr. 52:662674.

34) Tawaraya, K, Y. Takaya, M. Turjaman, S.J. Tuah, S.H. Limin, Y. Tamai, J.Y. Cha, T. Wagatsuma, and M. Osaki. 2003. Arbuscular mycorrhizal colonization of tree species grown in peat swamp forests of Central Kalimantan, Indonesia. Forest Ecol. Manag. 182:381-386.

35) Thomashow, L.S., and D.M. Weller. 1996. Current concepts in the use of introduced bacteria for biological control: mechanisms and antifungal metabolites, p. 187-235. In G. Stacey, and N.T. Keen (ed.), Plant-Microbe Interactions Vol. 1. Chapman and Hall, New York, USA.

36) Toyota, K., and M. Kimura. 1996. Growth of the bacterial wilt pathogen Pseudomonas solanacearum introduced into soil colonized by individual soil bacteria. Soil Biol. Biochem. 28:1489-1494.

37) Vallaeys, T., and G. Soulas. 1997. Pesticides: Microbial degradation and effects on microorganisms, p. 547-574. In J.D. van Elsas, J.T. Trevors, and E.M.H. Wellington (ed.), Modern soil microbiology. Marcel Dekker, New York, USA.

38) Valverde, A., P. Delvasto, A. Peix, E. Velazquez, I. Santa-Regina, A. Ballester, C. Rodriguez-Barrueco, C. Garcia, and J.M. Igual. 2006. Burkholderia ferrariae sp. nov., a novel bacterium isolated from an iron ore in Brazil. Int. J. Syst. Evol. Microbiol. 56:2421-2425.

39) Van Dijk, K., and E.B. Nelson. 2000. Fatty acid competition as a mechanism by which Enterobacter cloacae suppresses Phytium ultimum sporangium germination and damping-off. Appl. Environ. Microbiol. 66:5340-5347.

40) Van Overbeek, L., and J.D. van Elsas. 1997. Adaptation of bacteria to soil conditions: applications of molecular physiology in soil microbiology, p. 441-477. In J.D. van Elsas, J.T. Trevors, and E.M.H. Wellington (ed.), Modern soil microbiology. Marcel Dekker, New York, USA.

41) Wawrik, B., L. Kerkhof, J. Kukor, and G. Zylstra. 2005. Effect of different carbon sources on community composition of bacterial enrichments from soil. Appl. Environ. Microbiol. 71:6776-6783.

42) Whipps, J.M. 2001. Microbial interactions and biocontrol in the rhizosphere. J. Exp. Bot. 52:487-511.

43) Whipps, J.M., and B. Gerhardson. 2007. Biological pesticides for control of seed- and soil-borne plant pathogen, p. 479-501. In J.D. van Elsas, J.K. Jansson, and J.T. Trevors (ed.), Modern soil microbiology ( $2^{\text {nd }}$ ed). Marcel Dekker, New York, USA.

44) Zhang, H., S. Hanada, T. Shigematsu, K. Shibuya, Y. Kamagata, T. Kanagawa, and R. Kurane. 2000. Burkholderia kururiensis sp. nov., a trichloroethylene (TCE)-degrading bacterium isolated from an aquifer polluted with TCE. Int. J. Syst. Evol. Microbiol. 50:743-749.

45) Zhu, H.H., and Q. Yao. 2004. Localized and systemic increase of phenols in tomato root induced by Glomus versiformae inhibits Ralstonia solanacearum. J. Phytopathol. 152:537-542. 